\title{
The Development and Interregional Integration Processes of Afghanistan
}

\author{
Nuriddin Kayumov (Tajikistan Academy of Sciences, Tajikistan)
}

\begin{abstract}
The given report considers the integration processes within the Central Asian Region and EAEC region space and their influence on economic situation of Afghanistan. It is emphasized, that the globalization of the world economy, new challenges and threats, especially intraregional integration becomes the predominant tendency of the world economy. Today practically the whole world is considered as a complex regional coalition, union or federation. By integrating between each other these countries protect their corporative interests.

Central Asian sub-region has all prerequisites and possibilities of becoming the new zone for the world development. However, during the years of sovereignty and independence the integration processes even aggravated. Integration processes in the framework of EAEC region are also not effective. All these do not allow rendering assistance and support to the neighboring country Afghanistan. The situation in this country, especially in the sphere of economy constitutes a threat not only to the Central Asian countries, but also for USA, Russia, China and the whole world. The ways of solving Afghan problems lie in the sphere of economy. The author considers possibilities and ways of achieving peace and stability in this country.
\end{abstract}

JEL Codes: O19, F15, I15

\section{Introduction}

Today Afghanistan is the main crisis spot in the world. Here is the threat of not only the internal and external instability, but also threat of developing international terrorism and contraband of heroin. The problems of afghan society, drug production and traffic have become one of the most serious problems not only for Afghanistan itself, but for many countries of the world, whose policy is interrelated with this region.

In the recent years, activation of "Taliban" in the North of Afghanistan, in the province of Kunduz has taken place. The Kunduz province borders on Tajikistan and this may lead to escalation of tension in the Central Asia and possibility of attacks to the territory of Tajikistan. Such attacks have already taken place.

Tajikistan has a common border with Afghanistan, its length is $1400 \mathrm{~km}$. Afghanistan as well has a common border with Uzbekistan and hence the stability and safety of the whole Region depends on the situation in this country. Therefore, it is clear why the world community is anxious about the situation in Afghanistan. The International Conference on the issues of cooperation concerning Afghanistan is the evidence of it.

\section{Historical Developments}

As far as July 10-12, 2008 in Issik-kul (Kyrgyzstan) the International Conference «Afghanistan, the Shanghai Organization for Cooperation, Security and geopolitics of the Central Eurasia» took place, where a number of conclusions were formulated, as well some recommendations made regarding activation of entrepreneurial activities and attraction of foreign investments in order to restore the economy of Afghanistan.

According to the initiative of the Republic of Tajikistan on October 21-22, 2008 the International Conference on Afghanistan has been conducted in the Dushanbe. It was proposed at the conference to create a multi-level system of international cooperation, which is the essential condition for effective counteraction and counter measure against terrorism, drug production and drug traffic. According to the results of conference a joint Declaration on partnership was made that was intended for strengthening the regional cooperation for struggle against the international drugs contraband. The participants of the conference supported the OSCE project on training of border specialists and establishment of the specialized learning center for training and retraining of law-enforcement agencies of Tajikistan and Afghanistan.

At the London International Conference a decision was proposed to donor countries render financial assistance to Afghanistan in the amount of 10,5 billion USD for realization of program aimed to the country's economic development. Heretofore at international conferences in Berlin and Tokyo the world community has promised 9,0 billion USD for this purpose. However, according to some sources the mentioned financial means had no a considerable influence on the social and economic life of the country.

In Moscow (Russia), on June 9-10, 2010 an International Forum "Afghan drug production - challenge for the world community" was conducted, where the issues of security threat due to the growth of drug production and drug use not only for the Central Asian Region, but also for other countries of Asia and Europe were discussed.

These International Conferences and Forums considered the problems of Afghan society from the position of struggle against terrorism and drug traffic. Undoubtedly, the issues of struggle against terrorism, distribution of 
drugs, border protection and fortification are the most important problems. But without solution of social and economic problems, development of real sector of economy, creation of new jobs, aimed for reduction of unemployment in Afghanistan are impossible. The volume of drug turnover grows day by day just like in previous years.

\section{Economic Development of Afghanistan}

The principal stabilizing factor can be only the development of those branches of economy, which form the natural competitive advantage of Afghanistan.

Though, the economy of Afghanistan in the recent years is growing with the high rates - up to 12-13\% annually, absolute volumes of GDP are not so large, approximately 11,0 billion USD that makes up 460 USD per capita. Foreign trade turnover do not exceed even 4,0 billion USD. Donors' aid makes up 13-14 billion USD.

At the same time, according to some data the annual volumes of financial means generated by drug mafia make up more than 300 billion USD. For the last 10 years the income from drug traffic has grown 40 times, besides approximately

$30-35 \%$ of drug producers' and drug runners' income goes to the budget of "Taliban" movement that are used for the purchase of armaments, for struggle against opposition within the country and for expansion of international terrorist activities in other countries. Out of 65 billion USD that is annually yielded from the opium production, approximately 5 billion remain within the Afghanistan. This comparison shows that the income from drug business dozens of times exceeds the volumes of donor assistance and country's budget altogether. Therefore, under the current situation not only the international drug lords, but also the common farmers are not interested in curbing of drug production and drug business.

\subsection{Economic Integration}

The situation in the economy of Afghanistan can be cardinally changed first of all on the basis of intra-regional integration of the Central Asian countries, Eurasian community, EAEC region and other interested countries.

Strengthening of regional integration based on the creation of various economic blocs and unions becomes the predominant tendency of modern geopolitical and geo-economic processes. Integration has no alternative, and incorporation of economic lives of the Central Asian states would give an opportunity to the Central Asian countries to realize their corporate interests and withstand all new challenges and threats, which are mainly conditioned by globalization process in the world economy.

The world energy crisis, which happened due to increase in production and growth of population, exhaustion of once rich deposits of hydrocarbon raw materials, availability of large reserves in the zones of pioneering development as the Central Asia is, all of these may result in competition between the great powers, which are the center of world policy and economy, as well will lead to tensions and instability in the Region. The given circumstances assume joining of efforts for protection of one's own national interests, development of effective approaches and mutually beneficial cooperation based on the close intraregional integration. This, first of all will provide a reliable system of high complementarities for region's economic potential, and secondly, the Region may be of interest for foreign investors only as the entity and as a great outlet. Under such approach in the longer term the Central Asian Region might become a new zone of the world economic growth. However the current condition of integration relations in the Region are far from the civilization and do not satisfy the requirements of our time.

About 20 years has passed, but the countries of region failed to become integrated, and on the contrary the situation worsens from year to year. It is as if the countries are trying to do everything in order to escape from integration. In fact instead of integration the disintegration process is increasing. There are all necessary conditions and factors for the deep and effective intraregional integration: all the Central Asian Republics were the members of integrated country and related to one common economy. The countries of region inherited from the USSR great many of plants and factories, which are combined in a single technological and transport network, as well as experience of creating and exploiting the unified electric power system, long distance oil and gas pipe lines. Besides, we are united by the territorial proximity, commonness of history, cultural heritage, traditions, mentality of region's population, availability of richest natural, mineral resources, considerable human potential, input complementarities and cooperation ties, communication and transport infrastructures, presence of common economic problems, and common interest in the safety of the whole region.

\subsection{Relations with Tajikistan}

Within the last years trade and economic relations of Tajikistan and Afghanistan speed up. From 2000 up to 2009 it has grown in 26.3 times, including export - in 10.4 times. Though this relations are far from the normal level: export makes up 26.9 and import - 44.2 million USD. There is no doubt that in perspective, after new HPPs will be put into operation, railway, automobile and communication networks will be developed, the level of economic relations between the Tajikistan and Afghanistan achieves a new quality. 
Upon availability of favorable integration conditions Tajikistan could render a serious support to Afghanistan in developing its economy. Tajikistan possesses huge potential for development of hydropower industry - about 527 billion $\mathrm{kWh}$. Out of this volume only 3.0-3.5\% are used in fact. At present there are a lot of disputes regarding the Rogun HPP (Hydro Power Plant), which is one of the largest in the Region. As soon as this HPP will be put into operation, Afghanistan becomes one of the principal power consumers, only through territories of this country the electric power can be transferred up to Pakistan and Iran. Afghanistan has already developed its own program for transit of electric power from Tajikistan. At present the Indian Company has started the construction of power transmission lines on the territories of both countries in order to join them. Sometimes ago the Ministry of energy and Industry of Tajikistan and the Department of Energy of Afghanistan has concluded agreements on construction of power transmission lines, with the capacity of $220 \mathrm{kV}$ in Kunduz city. With the lapse of time these power transmission lines will reach the Takhor province through the territory of Puli Khumri city. Today $10 \mathrm{MW}$ (megawatt) of electric power is being transferred from Tajikistan to Kunduz. There is an agreement between the both parties to increase this quantity up to 40 megawatt. The Afghan party purchases electric power from Tajik company "Pamir energy", which is established within the framework of the Agha Khan Project.

With relation to development of productive powers of Afghanistan in perspective, ensuring energy security for Tajikistan and Afghanistan, development of huge land areas and solution of other social and economic problems of the Afghan society, the construction of Dashtijumsky HPP, which was one of the largest plants in the postSoviet area, is of enormous importance. Construction of the mentioned HPP will solve not only the problems of energy saving, but also the problem of developing hundred thousand ha of lands.

\subsection{Infrastructure projects}

Afghanistan is interested in construction of railways in the Central Asia. A railway form Uzbekistan up to Afghan city Mazori Sharif has already been constructed, and now it is planned to drive a railway up to Tajik city Nizhniy Pyanj, and from Nizhniy Pyanj up to Afghan port Sherkhon Bandar, where this line will be divided into two parts. One of the ways will be driven to Kabul and further up to the Ainak copper deposit on the border with Pakistan, and the other up to Mazori Sharif, where it will be connected with the Uzbek part of the railway. The railway line from Mazori Sharif will be driven to the Farab province, then to Gerat and from Gerat to Iran. The Iranian side has already driven a railway line up to Gerat. The Uzbek party has also completed its own part of railway up to Mazori Sharif city. The financial means are already available for construction of railway from Gerat up to Mazori Sharif. And as a result all these parts will be connected to each other, and then this railway system will be connected with the Pakistan. All of this will promote more fruitful development of economic cooperation between the Afghanistan and the Central Asian countries.

Bridges are of great importance in relations between the Tajikistan and Afghanistan, the bridges that are built in Ishkashim, Khorog, Nizhniy Pyanj and Darvaz. These bridges play the important role in transport network and development of trade. In Ishkashim and Nizhniy Pyanj a frontier trade is organized. These areas are considered as free economic zones. All this will serve as a serious factor for development of Afghanistan's economy.

\section{Conclusion and Recommendations}

In conclusion of my report, I would like to propose a number of recommendations and measures on rehabilitation of Afghanistan's economy.

Most probably the recovery period may be prolonged for many years, if the world community does not take cardinal measures on recovery of Afghanistan's economy. Development of Afghanistan is complicated by the presence of serious inhibitive factors. The country is less-developed and poor historically, it has no productive and non-productive infrastructure, with the low level of education and health care, lack of relevant sectors of industry, unskilled level of specialists, the landlocked situation, with no outlets to the sea, poor material and technical base of agrarian and other sectors of economy, financial dependence on external donors and lastly political instability.

Solution of these complex problems should be through development of effective measures not only by the Government of Afghanistan, but also jointly with the interested countries, measures on the state economic policy. In order to realize this goal it is necessary to develop a long-term program for economic development of Afghanistan in perspective for the period of 20 years, with the precise definition of realization stages, objectives and financial support. The most important priorities should be determined.

As it is known Afghanistan - is a typical agricultural country with the backward material and technical base, low crop yield and productivity. Up to $38-40 \%$ of country's GDP falls to the portion of agriculture. More than $50 \%$ of population is the poor/vulnerable people, who live in rural areas. About the half of plough-lands are being irrigated artificially, the water in this country is the tight resource. Despite all these limitations the condition of agriculture is determinative for country's economy and should be considered as the issue of higherpriority. Specialization of this branch should be orientated to the development of those productions, which can 
serve as the basis for development of light, food and process industries. The production should be focused on the final output.

It is necessary for the Government of Afghanistan to develop and realize the program of shifting the agricultural sector to the industrial basis, according to the principal of "green revolution", with the view to provide its food safety.

Nevertheless, the agrarian model of developing economy is the dead-locked one. Therefore with the view of employing labor resources and increasing the economic efficiency, it is necessary to develop higher-priority branches of industry. The Government of Afghanistan should be focused on industrial and agrarian model of development. It is possible also in addition to the light and food industries develop processing and mining industries and natural gas extraction.

In the 80 s of the last century a considerable part of Tajikistan's demand in natural gas was provided through delivery from Afghanistan. Activation of geological exploration works, prospecting of new raw hydrocarbon deposits, will substantially lower the dependence of country on import of oil and gas from the Arabic countries.

The country can gain a huge profit from cotton production with its complete processing within the country. Afghanistan possesses sufficient potential for development of export industries and import substitution. In due time, the USSR had built 142 objects within the framework of program on rendering the technical assistance to Afghanistan. At present they are almost totally destroyed. Now it is necessary to think of their reconstruction. Certainly reformations in the sphere of economy are not possible without the well-considered reforms.

The world community renders the actual financial assistance to Afghanistan, but it is not sufficient. Investment activity of donor countries, who has undertaken the economic recovery of Afghanistan do not satisfy the needed requirements. For instance, out of the promised in 2002-2006 years amount of 30 billion USD only 13 billion USD was allotted, including through the Ministry of Finance 3,7 billion Such approach also took place in subsequent years.

The major contributions should be done first of all by USA, European Union and other interested countries. Afghanistan should enter the orbit of integration processes of countries-members of the Eurasian community. Many member nations of these unions, in particular China, Russia, Kazakhstan and some other countries possess a powerful economic and financial potential, which under effective integration can provide not only their own development, but as well the economic growth in Afghanistan.

All mentioned steps/measures should be aimed at creation of healthy economic system, which is a good chance for stabilizing the economic and political situation in the country, and the way out of systemic crisis. There is no other way.

On the other hand, the Government of Afghanistan, donor countries have to tighten control over the utilization of financial means. The facts of inefficient use of investments, intended for the recovery of economy, more than $50 \%$ of technical aid is totally inadmissible. According to the data of the Government of Afghanistan out of 9 billion USD, only $22 \%$ are spent for development of economy, and $50 \%$ are in hands of various NGOs, which have received the financial assistance bypassing the Government. Out of 2355 NGOs existing in the country 1950 are busy with money-laundering. As a result of conducted re-registration 1620 NGOs have disappeared, out of them 333 - are foreign NGOs.

Financial resources allotted by the world community for economic recovery of Afghanistan, in fact, are not used according to the intended purposes and squandered by mafia structures.

Thus, the solution of Afghan systemic crisis requires not only multilateral military and political, diplomatic, but also mainly the social and economic strategy. I believe that Afghanistan has serious preconditions for solving its geopolitical and geo-economic problems.

\section{References}

- Bulassa B. The Theory of Economic Integration. - London, 1962. - P. 2;

- The projects of cooperation and integration for CA countries, Comparative analysis, capabilities and perspectives, Bishkek 2007, pp. 28;

- Morris Shiff, L. Alan Winters., "Regional integration and development”, Moscow, "Ves mir", 2005, pp. 199;

- Tajikistan and CIS countries Goscomstat of RT, Dushanbe, 2009. p.p. 26.27.28.29. 